\title{
ORGANISMOS GENETICAMENTE MODIFICADOS: UMA ANÁLISE À LUZ DO PRINCÍPIO DA PRECAUÇÃO
}

\author{
Christiane Vincenzi Moreira Barbosa ${ }^{1}$ \\ Lino Rampazzo ${ }^{2}$
}

Resumo:

O objetivo deste artigo é abordar os organismos geneticamente modificados, e, mais especificamente, os transgênicos, considerando os seus riscos. Discute-se o princípio da precaução e sua importância no contexto do cultivo e do consumo desses alimentos. Mais especificamente, diz respeito à atual realidade brasileira, uma vez que o país ocupa o segundo lugar entre os que possuem maior área destinada ao cultivo de transgênicos.

Palavras-chave:

Organismos Geneticamente Modificados, Transgênicos, Princípio da Precaução, Riscos, Alimentos.

\section{GENETICALLY MODIFIED ORGANISMS: AN ANALYSIS IN THE BASED ON THE PRECAUTIONARY PRINCIPLE}

Abstract:

The purpose of this article is to address genetically modified organisms, and, more specifically, transgenic ones, considering their risks. There is discussion of the precautionary principle and its importance in the context of the cultivation and consumption of these foods. More specifically, the current Brazilian reality is discussed, since the country ranks second among those with the largest area for the cultivation of transgenics.

Keywords:

Genetically Modified Organisms, Transgenics, Precautionary Principle, Risks, Foods.

\section{INTRODUÇÃO}

Com o avanço da engenharia genética surgiu a possibilidade de se criarem organismos geneticamente modificados, com a vantagem de trazerem ao consumo alimentos mais saborosos, nutritivos e baratos. No entanto, muitos riscos envolvem essa prática, razão pela qual deve ser invocado o princípio da precaução.

\footnotetext{
${ }^{1}$ Mestra em Direito pelo Centro Universitário Salesiano de São Paulo

2 Pós-Doutor em Democracia e Direitos Humanos pela Universidade de Coimbra/Ius Gentium Conimbrigae. Graduado em Filosofia pela Faculdade Salesiana de Filosofia Ciências e Letras de Lorena (1986) e em Teologia pelo Pontificio Seminário Regionale di Chieti (1970). Mestre (1975) e Doutor (1978) em Teologia pela Pontifícia Universidade Lateranense. Professor e pesquisador do Centro Universitário Salesiano de São Paulo. Coordenador e professor do Curso de Teologia da Faculdade Canção Nova.
} 
O Brasil atualmente é o segundo país com maior área ocupada pelo cultivo de transgênicos, cujas regras proibitivas vêm sendo a cada ano mais flexibilizadas.

Diante desse cenário, faz-se necessária uma discussão acerca dos riscos que envolvem o cultivo e o consumo de transgênicos, bem como da necessidade de que esses riscos sejam levados em consideração na prática agropecuária brasileira.

Busca-se, no presente artigo, como objetivo geral, fazer uma breve análise do princípio da precaução, bem como, mais especificamente, estabelecer um paralelo entre esse princípio e os riscos que envolvem o cultivo de organismos geneticamente modificados no Brasil.

Justifica-se o desenvolvimento deste trabalho pela relevância que o tema possui e pela imprescindibilidade de que seja abordado de maneira crítica. A discussão sobre esse assunto, de enorme atualidade, leva a muitos questionamentos no âmbito da Bioética e do direito ambiental.

A pesquisa será realizada por meio de levantamento bibliográfico e documental.

\section{OS ORGANISMOS GENETICAMENTE MODIFICADOS (OGM) E OS RISCOS QUE OS ENVOLVEM}

O uso crescente da biotecnologia na produção de alimentos apresenta-se como solução para a dificuldade em se prover nutrição de qualidade à crescente demanda causada pelo aumento da população. Não há dúvidas no sentido de que fatores como o sabor e a durabilidade desses alimentos os tornem mais interessantes ao consumo. Além disso, a possibilidade de se trazerem produtos geneticamente modificados ao mercado, traz consigo a possibilidade de torná-los mais nutritivos, o que consiste em relevante diferencial no atual cenário de carências alimentares (VARGAS et al., 2018).

No entanto, esse tipo de prática não apresenta apenas aspectos positivos, também carregando consigo uma série de riscos que serão analisados mais adiante (RIBEIRO; MARIN, 2012).

Nesse sentido, passa-se a seguir à apresentação do conceito de Organismos Geneticamente Modificados, para que, em seguida, possam ser ponderados os seus efeitos positivos e negativos.

\subsection{CONCEITOS RELEVANTES QUE ENVOLVEM OS ORGANISMOS GENETICAMENTE MODIFICADOS}


Incontáveis inovações no campo da Biotecnologia abriram campo para o surgimento dos OGM (sigla para organismos geneticamente modificados). Dentre eles, pode-se inequivocamente citar a descoberta do DNA ou ADN (sigla para Ácido Desoxirribonucleico), pelo médico norte-americano Oswald Theodore Avery (ULTCHAK, 2018, p. 125).

Em razão da complexidade e do caráter técnico do tema, embora não se busque aqui dissecar o assunto ao ponto de esgotá-lo, faz-se mister a apresentação de alguns conceitos para que se possa estabelecer uma análise ética a seu respeito. Desse modo, antes de se partir à definição dos organismos geneticamente modificados (OGM), passar-se-á à definição de alguns termos correlatos.

Em primeiro lugar, é imprescindível que se determine a concepção de DNA, que é uma molécula que carrega consigo todo o código que determina a hereditariedade em organismos vivos. Com a descoberta de novas técnicas de manipulação genética, tornou-se possível realizar a alteração dessa molécula, modificando-se as características do organismo de forma preestabelecida (BARTH, 2005, p. 363).

Os genes são pequenos trechos da molécula de DNA que possuem a função de armazenar características dos seres vivos. Genoma, por seu turno, é o conjunto formado por todos os genes de um organismo, é todo o código genético daquele ser. A expressão do genoma constitui o fenótipo, ou seja, é o conjunto das características que o indivíduo possui, de acordo com o que determinam os seus genes (BARTH, 2005, p. 363).

Por sua vez, a manipulação genética, para Maria Helena Diniz (2017, p. 421-422):

É uma técnica de engenharia genética que desenvolve experiências para alterar o patrimônio genético, transferir parcelas do patrimônio hereditário de um organismo vivo a outro ou operar novas combinações de genes para lograr, na reprodução assistida, a concepção de uma pessoa com caracteres diferentes ou superar alguma enfermidade congênita.

Os organismos geneticamente modificados (OGM) são, assim, aqueles que sofreram alterações em seu genoma, de maneira a se inserirem características desejáveis ou se suprimirem aquelas consideradas desfavoráveis, por meio de técnicas de engenharia genética. Não se confundem com os transgênicos, que são espécies do gênero OGM (VARGAS et al, 2018, p. 20).

Os transgênicos são aqueles organismos cuja modificação implicou a inserção de genes de outras espécies, que não seriam capazes de cruzar entre si no ambiente natural (BARTH, 2005, p. 364). Por razões óbvias, estes são alvo de muito maior preocupação, tendo 
em vista o fato de não serem dominadas todas as possibilidades que envolvem essas modificações.

O que antes era visto como mero debate científico, hoje passa a fazer parte do dia a dia do consumidor, uma vez que os OGM estão nas prateleiras dos supermercados, para aquisição por muitos que sequer entendem o que há por trás dos símbolos nos rótulos das embalagens. Desse modo, é necessário que se estabeleçam questionamentos sobre os possíveis efeitos dessa prática à luz do princípio da precaução.

Além disso, é interessante que se discutam os possíveis efeitos da intervenção do homem na natureza. Para isso, é de bom tom citar alguns exemplos históricos.

\subsection{A INTERVENÇÃO HUMANA NA NATUREZA}

Como se sabe, não é recente a interferência do ser humano no meio ambiente, e mesmo na reprodução de animais e de plantas. Desde tempos imemoriais, é realizada a promoção do cruzamento entre espécies com o propósito de melhorá-las. A própria Bíblia, no livro de Gênesis menciona a separação do gado para escapar-se à perda da pureza das raças (ROSA; MENEZES; EGITO; 2013, p. 12-13).

Não se pode olvidar que esse tipo de prática levou a um fenômeno conhecido como “erosão gênica”, que consiste na redução da diversidade dentro de uma dada espécie (BRAMMER, 2002). Além da erosão gênica, muitas outras consequências inesperadas surgiram, uma vez que o homem não domina todos os fatores que envolvem o equilíbrio ambiental. Um outro exemplo é o cultivo de plantas que produzem frutos mais doces e saborosos, levando à extinção das espécies geradoras de frutos azedos ou amargos, o que tornou os alimentos hoje consumidos menos nutritivos.

Assim, a manipulação genética não ocorria de forma direta, no genoma do organismo, mas era realizada na prática, ao se cruzarem espécies que portassem os melhores caracteres, deixando-se de lado outras menos favorecidas fenotipicamente. A seleção artificial, nome dado a essas práticas, não se restringiu ao passado, ocorrendo até os dias atuais. O que não se pode olvidar é que a intervenção humana na natureza geralmente está cercada de incertezas, por não haver o domínio completo de suas consequências, principalmente no médio e no longo prazo.

Um exemplo bastante interessante que merece menção, foi a introdução de uma espécie de coelhos europeus na Austrália, no século XVIII. Esses coelhos encontraram um 
ambiente muito favorável, com grande disponibilidade de alimentos, assim como ausência total de predadores. A consequência disso foi a sua reprodução desordenada, dizimando plantações e se tornando uma verdadeira praga (O VÍRUS, 2018).

Esse episódio deixa claro o quanto é perigoso intervir no ambiente ecologicamente equilibrado. Isso porque há riscos imprevisíveis que envolvem essas práticas e não podem ser desconsiderados. Daí a necessidade de se considerar o princípio da precaução, que será abordado mais detalhadamente em item subsequente.

\subsection{OS BENEFÍCIOS DOS ORGANISMOS GENETICAMENTE MODIFICADOS (OGM) NO CONTEXTO CONTEMPORÂNEO}

Como já afirmado, os Organismos Geneticamente Modificados (OGM) são produzidos e liberados para o consumo, na maioria dos casos, com o objetivo de se disponibilizarem alimentos mais baratos e com qualidade superior no mercado. No que tange à redução de preços, esta foi tornada possível pelo aumento da produtividade, que está relacionada tanto aos OGM, quanto ao uso de agrotóxicos e fertilizantes, além de outras tecnologias, como a mecanização das lavouras.

Abaixo, reproduz-se um gráfico que demonstra o aumento da produção agrícola nos últimos anos, até 2018.

Gráfico - Rendimentos de colheita, Mundo, 1961 a 2018 


\section{Crop yields, World, 1961 to 2018 \\ Crop yields are measured in tonnes per hectare.}

\section{$\rightleftarrows$ Change country $\quad \square$ Relative change}

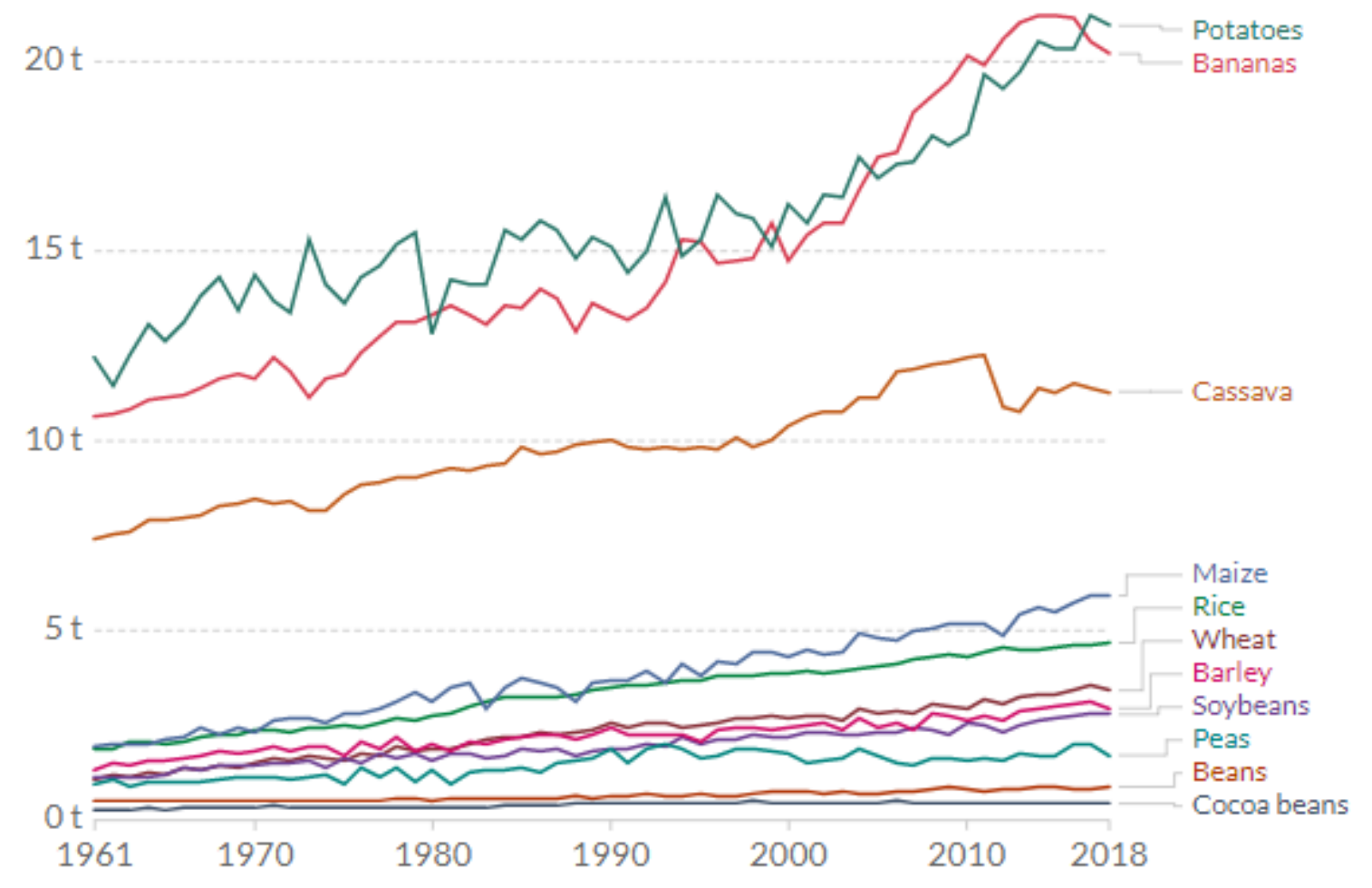

Source: UN Food and Agricultural Organization (FAO)

Fonte: CROP YELDS, 2018.

Do referido gráfico é possível se depreender que o uso da biotecnologia agrícola possibilitou a ampliação das colheitas, aumentando a disponibilidade de alimentos. Seguindo essa linha de raciocínio, há muitas vantagens em seu emprego, e isso não pode ser desconsiderado.

Além disso, os Organismos Geneticamente Modificados têm o seu DNA alterado, muitas vezes, para torná-los mais resistentes a pragas, o que tem impacto no uso de agrotóxicos. Outra questão relevante é o fato de esses organismos exigirem menor uso de agroquímicos, os quais têm seu uso excessivo associado a desequilíbrios ambientais (HERMANN, 2020).

Nessa linha de raciocínio, os transgênicos e outros OGM são capazes de ajudar na sustentabilidade ambiental, por permitirem menor uso de inseticidas, além de possibilitarem 
menos perdas de colheitas. Isso claramente tem o condão de beneficiar o meio ambiente, uma vez que, quanto mais se pode produzir com menos recursos, menor é o impacto ambiental.

No entanto, não devem ser considerados apenas os efeitos benéficos do uso dessas tecnologias, visto haver também riscos envolvidos, como será abordado adiante.

\subsection{OS RISCOS ENVOLVENDO OS ORGANISMOS GENETICAMENTE MODIFICADOS (OGM)}

Os alimentos transgênicos possuem um símbolo representado por um "T" amarelo em suas embalagens. Essa informação tem por objetivo esclarecer os consumidores acerca da origem do produto que estão adquirindo nos mercados (SAIBA, 2019).

Todavia, a verdade é que a divulgação de informações acerca dos Organismos Geneticamente Modificados - OGM é muito escassa e não atinge toda a população que os consome. Além disso, muitos desses alimentos são utilizados para a produção de rações para o gado, os suínos e as aves, bem como estão presentes em alimentos processados como salsichas (SAIBA, 2019).

Nesse sentido, é de inquestionável relevância que sejam avaliados os riscos por trás do uso dessas tecnologias, uma vez que não apenas as vantagens devem ser consideradas.

Em primeiro lugar, deve-se levar em conta a falta de conhecimentos precisos a respeito dos impactos que a liberação no meio ambiente de organismos geneticamente modificados pode acarretar.

Dentre esses riscos ecológicos, deve ser mencionada a possibilidade de erosão da diversidade das espécies, bem como a transferência horizontal de genes, causando prejuízos a organismos não alvo. Um exemplo desse último seria afetar insetos não alvo, que, inclusive, poderiam ser a principal presa na cadeia alimentar de outras espécies (COSTA et al., 2011).

A inserção de plantas geneticamente modificadas no meio ambiente poderia contaminar outras plantas, que poderiam também vir a se tornar "super-pragas", ou seja, espécies de ervas daninhas super resistentes a venenos. Isso exigiria maior quantidade de agrotóxicos, o que poderia aumentar consideravelmente a poluição em rios e no solo (SAIBA, 2019).

É de bom tom lembrar que a natureza não para de evoluir pela intervenção humana. Ou seja, novas cepas de organismos continuam se desenvolvendo, e isso inclui o aumento da resistência de pragas e vírus às toxinas implantadas nos transgênicos, o que os levaria a perder sua eficácia (COSTA et al., 2011). Isso quer dizer que não há um controle por parte dos 
detentores da tecnologia do que ocorrerá posteriormente, após a liberação dos OGM no ambiente natural.

Ainda devem ser levados em consideração os possíveis efeitos de longo prazo na saúde humana, causados pela ingestão dos OGM. São os riscos alimentares. Há perigos em potencial associados a esse consumo, como alergias, intoxicações e intolerância. O maior problema por trás disso é que esses efeitos não são previsíveis, mesmo com o respeito a todos os protocolos de segurança e condução de testes (COSTA et al., 2011).

As alergias ocorrem porque as novas combinações de genes podem não ser toleradas por muitas pessoas. Outro fator é o alimento passar a carregar genes de outras espécies, que podem causar reações nos alérgicos ao organismo doador dos genes (SAIBA, 2019).

Uma outra questão é o grau de toxicidade desses alimentos, que muitas vezes são modificados para gerar substâncias que matam pragas. Essas substâncias, quando presentes naturalmente nos organismos em baixas quantidades, não são propriamente tóxicas à saúde humana, mas em altas quantidades podem causar nela uma série de reações. Além disso, a inserção de genes marcadores de bactérias resistentes a antibióticos nesses organismos, pode aumentar a resistência a antibióticos em organismos humanos.

Também há um outro fator que precisa ser considerado. Trata-se do fato de os agricultores que utilizam a tecnologia terem que pagar royalties aos que a detêm. Caso optem por não as utilizarem, acabam por não terem competitividade com aqueles que as aplicam, pelo fato de sua produção ser mais cara. Isso, no longo prazo, tornará inviável a produção agropecuária que não envolva os OGM (SAIBA, 2019).

Um outro problema refere-se à impossibilidade de se recolherem totalmente as plantas liberadas no meio ambiente, caso se tornem por algum motivo indesejáveis. Elas se alastram para outras propriedades e deixam rastros pelo solo daquela que ocupavam, fazendo com que novas plantações ali realizadas se contaminem.

Como se pode notar, há muitos riscos envolvendo os Organismos Geneticamente Modificados (OGM), razão pela qual sua produção e seu consumo devem ser regulamentados de forma rígida. A seguir, será apresentada a Lei de Biossegurança, que atualmente regula os OGM no Brasil, assim como vai ser feita uma contextualização da forma de tratamento desses organismos por outros países do mundo. 


\title{
3 O TRATAMENTO DOS ORGANISMOS GENETICAMENTE MODIFICADOS NO BRASIL E NO MUNDO
}

Consideram-se, a seguir os diplomas legais que tratam dos OGM no Brasil, bem como julgados que envolvem diretamente o tema.

\subsection{A LEI DE BIOSSEGURANÇA}

É relevante que, nesse contexto, se defina biossegurança. Segundo a Food and Agriculture Organization (FAO), a biossegurança se traduz no uso de produtos biotecnológicos com respeito à saúde humana e à sustentabilidade para o meio ambiente, respeitando-se a biodiversidade existente no Planeta (FOOD AND AGRICULTURE ORGANIZATION, 1999). Isso inclui também a necessidade de que se esclareça o consumidor acerca desses produtos, com a informação clara e padronizada a seu respeito nos rótulos das embalagens.

A atual Lei de Biossegurança vigente no Brasil é a Lei n. 11.105, de 24 de março de 2005, que revogou a Lei $n^{\circ} 8.974$, de 05 de janeiro de 1995. Essa lei criou a Comissão Técnica Nacional de Biossegurança - CTNBio, um órgão multidisciplinar, definida em seu artigo 10, transcrito a seguir:

\begin{abstract}
Art. 10. A CTNBio, integrante do Ministério da Ciência e Tecnologia, é instância colegiada multidisciplinar de caráter consultivo e deliberativo, para prestar apoio técnico e de assessoramento ao Governo Federal na formulação, atualização e implementação da PNB de OGM e seus derivados, bem como no estabelecimento de normas técnicas de segurança e de pareceres técnicos referentes à autorização para atividades que envolvam pesquisa e uso comercial de OGM e seus derivados, com base na avaliação de seu risco zoofitossanitário, à saúde humana e ao meio ambiente.

Parágrafo único. A CTNBio deverá acompanhar o desenvolvimento e o progresso técnico e científico nas áreas de biossegurança, biotecnologia, bioética e afins, com o objetivo de aumentar sua capacitação para a proteção da saúde humana, dos animais e das plantas e do meio ambiente. (BRASIL, 2005).
\end{abstract}

Essa lei também define os organismos geneticamente modificados como "organismo cujo material genético - ADN/ARN tenha sido modificado por qualquer técnica de engenharia genética" e organismo como: "toda entidade biológica capaz de reproduzir ou transferir material genético, inclusive vírus e outras classes que venham a ser conhecidas" (BRASIL, 2005).

Além dessa lei, é importante a menção ao Decreto n. 4.680, de 24 de abril de 2003, trata da rotulagem dos alimentos e ingredientes alimentares destinados ao consumo humano 
ou animal que contenham ou sejam produzidos a partir de organismos geneticamente modificados (BRASIL, 2003).

A CTNBio tem a competência de estabelecer normas para as pesquisas com OGM, classificá-los, acompanhar seu desenvolvimento, avaliar seu grau de risco e autorizar sua comercialização, além de outras atribuições. Todavia, põe-se em questão se seus pareceres são realmente isentos, tendo em consideração o fato de o agronegócio no Brasil sustentar o superávit comercial e os interesses dos detentores do poder econômico serem muitas vezes tomados como mais relevantes do que as reais necessidades da sociedade (ULTCHAK, 2018, p. 127).

A imparcialidade da CTNBio pode ser comprovada na publicação recente que facilita a liberação de organismos geneticamente modificados no Brasil. Trata-se da Resolução Normativa n. 24, que dispõe sobre normas para liberação comercial e monitoramento desses organismos, baixada em 7 de janeiro de 2020. Essa norma permite que os estudos para avaliação do potencial de risco de um determinado alimento modificado geneticamente sejam realizados pela própria empresa que tem a intenção de comercializá-lo (OLIVEIRA, 2020).

Não há qualquer dúvida quanto ao fato de que dificilmente uma empresa que pode obter mais lucros com um determinado produto se interesse em elaborar um parecer contrário ao seu uso. Isso pode ser facilmente depreendido do fato de que a própria propaganda em relação aos benefícios e efeitos danosos desses produtos já vir sendo manipulada. Nesse sentido:

Em 2012, cientistas chefiados por Gilles-Eric Séralini, da Universidade de Caen, publicaram estudo inédito que demonstrou efeitos crônicos em ratos alimentados com milho transgênico NK 603 e o herbicida Roundup (glifosato), ambos da Monsanto. A revista científica Food and Chemical Toxicology publicou o estudo, que acabou "despublicado" devido a pressões da Monsanto. Entre elas, mudança no conselho editorial da publicação, com a entrada de um ex-funcionário da empresa. Houve também grande campanha de desqualificação técnica do trabalho e dos pesquisadores. (OLIVEIRA, 2020).

Nesse sentido, uma ação direta de inconstitucionalidade, a ADI 3526 de 2005, tramita no Supremo Tribunal Federal, questionando a competência da CTNBio de liberar os transgênicos no Brasil. Abaixo estão elencadas as liberações realizadas por esse órgão:

Há pareceres inclusive da presidência da República e do Ministério de Ciência, Tecnologia e Inovações contra a medida. Em seu relatório o MCTI destaca o trabalho da CTNBio nos 16 anos de atuação: na área de plantas foram aprovadas para comercialização 17 variedades de soja geneticamente modificada, 51 variedades de milho, 22 variedades de algodão, 5 de cana-de-açúcar, uma de feijão e uma de eucalipto, totalizando 97 processos. No total foram avaliadas 114 plantas. (MALISZEWSKI, 2021). 
Isso é preocupante uma vez que, como será tratado abaixo, o Brasil é o segundo país com maior produção de transgênicos em todo o mundo.

\subsection{OS TRANSGÊNICOS NO BRASIL E NO MUNDO}

O Brasil, no que tange à área destinada ao cultivo de transgênicos, perde apenas para os Estados Unidos, ficando a Argentina em terceiro lugar. Essa afirmação se baseia em dados colhidos e organizados pelo Serviço Internacional para a Aquisição de Aplicações da Agrobiotecnologia (ISAAA, na sigla em inglês) e causa grande preocupação (CAMPO, 2018).

Abaixo são reproduzidos dados bastante atuais sobre a produção de transgênicos no Brasil e no mundo:

Em 2019, foram 52.8 milhões de hectares cultivados, 1.6 milhão de hectares a mais (3\%) que em 2018. Os Estados Unidos permaneceram em primeiro lugar (71.5 milhões de hectares), e depois do Brasil vieram a Argentina (24 milhões de hectares), o Canadá (12.5 milhões de hectares) e a Índia (11.9 milhões de hectares). A soja geneticamente modificada ocupou 35.1 milhões de hectares no Brasil, área $15 \%$ superior à ocupada pela oleaginosa nos EUA, de 30.43 milhões de hectares. $\mathrm{O}$ milho transgênico foi plantado em 16.3 milhões de hectares no País, o algodão em 1.4 milhão de hectares e a cana-de-açúcar em 18.000 hectares.

Em termos globais, a área plantada com transgênicos caiu 0,70\% na comparação anual, para 190.4 milhões de hectares.

No caso da soja, recuou 4\%, para 91.9 milhões de hectares, equivalentes a $48 \%$ da área mundial com a tecnologia, muito embora a taxa média de adoção de biotecnologias tenha crescido nos países líderes, de 2018 para 2019, passou de $93 \%$ a $94 \%$ no Brasil.

Um total de 71 países consome produtos transgênicos, 42 estão abertos à sua importação e 29 realizam seu plantio. De 2018 para 2019, três países da África foram adicionados ao grupo dos produtores (Malaui, Nigéria e Etiópia). O continente é considerado o que tem mais potencial de crescimento em área cultivada, por conta da pobreza de algumas regiões e da necessidade de enfrentar a fome. (EUA e BRASIL, 2020).

Trata-se de algo preocupante, uma vez que a regulação dos produtos transgênicos vem claramente sofrendo flexibilização, especialmente no Brasil, país que não lidera as pesquisas no assunto, mas que está no topo quando se trata de destinar áreas para sua produção.

A respeito dessa flexibilização, será citado um exemplo a seguir.

\subsection{O CASO DA SOJA GENETICAMENTE MODIFICADA ROUNDUP}

A Roundup Ready (RR) é uma espécie de soja transgênica tolerante a herbicidas, que, em decorrência do glicosato, é capaz de eliminar ervas daninhas. A empresa que detém essa tecnologia é a Mosanto (NOGUEIRA JUNIOR, 2005). 
Ela foi liberada para o consumo em 2003, pela Medida Provisória n. 131, somente temporariamente, no que dizia respeito à safra dos anos de 2003/2004. O IDEC (Instituto Brasileiro de Defesa ao Consumidor), assim como muitos outros órgãos se posicionaram contra o incidente. No entanto, essa MP se transformou em lei, permitindo o plantio por mais tempo (SOJA, 2003).

Há algo que não pode ser olvidado, que é o fato de que as sementes de soja transgênica foram introduzidas no Brasil de maneira ilegal, visto ser o seu cultivo proibido. Assim, a já mencionada MP n. 131, de 2003, bem como as MP n. 113, MP n. 223 e MP n. 327, foram autorizando o cultivo e a legalização das produções irregulares, nos períodos entre 2003 e 2005. Posteriormente, como o tema não foi adequadamente regularizado, foi editada nova medida provisória, qual seja, a MP n. 327, trazendo mais flexibilizações. Nesse sentido:

\begin{abstract}
A polêmica em torno dessa medida nasce no momento em que são adicionadas emendas, aprovadas pelo relator, que flexibilizaram o rigor do texto original. A primeira alteração autoriza o beneficiamento e a comercialização de fibras de algodoeiros geneticamente modificadas, plantadas ilegalmente em 2006, para resistência ao herbicida glifosato. A segunda emenda refere-se à redução do quorum da CTNBio, necessário para a aprovação da liberação comercial de um OGM, de 2/3 dos representantes (18 membros) para maioria absoluta (14 membros). (CAMARA; GUILAM; NODARI, 2013, p. 30).
\end{abstract}

A MP 327 foi muito debatida e alvo de muitas polêmicas. Entretanto, no dia 21 de março de 2007 foi essa convertida na Lei 11.460, demonstrando claramente a tolerância no que diz respeito ao plantio de transgênicos no país (CAMARA; GUILAM; NODARI, 2013, p. $30)$.

O fato de o presidente à época da MP 113 haver cedido à pressão por parte da empresa Monsanto e dos produtores de soja ilegalmente cultivada anteriormente a esse período, a despeito dos riscos envolvidos, causa sérias preocupações no âmbito da Bioética.

Tendo em vista os riscos que envolvem os organismos geneticamente modificados, entende-se que deva a eles ser aplicado o princípio da precaução, que será explicado a seguir.

\title{
4 O PRINCÍPIO DA PRECAUÇÃO: CONCEITO E APLICACÃO
}

A partir de agora, passar-se-á a uma breve análise acerca do princípio da precaução, assim como explicar-se-á a necessidade de se considerá-lo quando da permissão do cultivo de transgênicos no Brasil.

\subsection{O PRINCÍPIO DA PRECAUÇÃO}


Entende-se que o princípio da precaução esteja previsto na própria Constituição Federal, como um dos princípios do Direito Ambiental. Isso se depreende da análise do artigo 225 , parágrafo $1^{\circ}$, inciso $\mathrm{V}$, conforme reprodução in verbis:

\footnotetext{
Art. 225. Todos têm direito ao meio ambiente ecologicamente equilibrado, bem de uso comum do povo e essencial à sadia qualidade de vida, impondo-se ao Poder Público e à coletividade o dever de defendê-lo e preservá- lo para as presentes e futuras gerações.

$\S 1^{\circ}$ Para assegurar a efetividade desse direito, incumbe ao Poder Público:

$(\ldots)$

V - controlar a produção, a comercialização e o emprego de técnicas, métodos e substâncias que comportem risco para a vida, a qualidade de vida e o meio ambiente. (BRASIL, 1988).
}

O princípio da precaução pode ser definido como aquele que tem por objetivo garantir uma mínima margem de segurança a alguma situação que apresente risco potencial. Se não houver certeza científica a respeito dos efeitos de uma determinada prática, os seus riscos precisam ser cautelosamente ponderados (OLIVEIRA FILHO, 2014, p. 8).

A avaliação do risco deve ser realizada com bases científicas e deve ser realizada diante da existência de incertezas. Assim, sua aplicação quanto aos organismos geneticamente modificados é incontroversa, tendo em vista não haver suficientes estudos quanto aos efeitos de longo prazo, decorrentes de seu cultivo e consumo.

\subsection{A APLICAÇÃO DO PRINCÍPIO DA PRECAUÇÃO NO CASO DOS TRANSGÊNICOS E OUTROS ORGANISMOS GENETICAMENTE MODIFICADOS}

Em países da União Europeia, Ásia e África, o princípio da precaução é incisivamente aplicado quanto a organismos geneticamente modificados. Uma das razões disso são os questionamentos a respeito da segurança dessas tecnologias e quanto a elas estarem ou não de acordo com o Guia Internacional para Segurança em Biotecnologia (IGSB) aceito pelo Programa Ambiental das Nações Unidas (COSTA et al., 2011).

Como não há certezas quanto aos efeitos produzidos pelo cultivo e pelo consumo de alimentos transgênicos, todo o cuidado é pouco. Já foram mencionados alguns dos riscos que os envolvem, tanto em questões ambientais quanto alimentares.

Quando da conversão da MP n. 327 em lei, muitos parlamentares mencionaram a necessidade de se observar o princípio da precaução. Isso porque o próprio princípio traz consigo a determinação de que a falta de certeza sobre os riscos não pode ser usada para minimizá-los (CAMARA; GUILAM; NODARI, 2013, p. 29). 
Não se pode desconsiderar que os riscos que aqui se ponderam são irreversíveis, podendo trazer consequências impensáveis tanto para a saúde pública quanto para o meio ambiente.

Todavia, como observado, esse princípio vem sendo desprezado, e cada vez mais se flexibilizam as regras que envolvem os transgênicos. Isso é inaceitável, independentemente do argumento utilizado, especialmente em um contexto mundial em que as normas restringindo a prática são mais severas.

Nesse sentido, conclui-se que, quando interesses econômicos se mostram mais importantes do que o meio ambiente e a saúde da população de um país, faz-se mister uma reavaliação de todo o sistema que nele vigora.

\section{CONCLUSÃO}

Conforme se depreende do acima exposto, importantes descobertas científicas trouxeram ao mundo contemporâneo novas possibilidades em vários campos e uma delas diz respeito ao setor agropecuário.

Embora o ser humano sempre tenha realizado a seleção artificial de animais e plantas, com o surgimento técnicas modernas de engenharia genética, e, consequentemente, dos organismos geneticamente modificados, dentre os quais os transgênicos merecem destaque, essa prática passou a se tornar alvo de maior preocupação.

Naturalmente, há benefícios na modificação genética de organismos para o consumo, os quais incluem o aumento da produtividade e o incremento na qualidade e no sabor desses alimentos.

No entanto, junto com os benefícios, muitos riscos também surgem, especialmente por não se conhecerem os efeitos de longo prazo tanto do cultivo quanto do consumo desses alimentos. Erosão das espécies geneticamente modificadas, transferência horizontal de genes, criação de pragas, alergias alimentares e intoxicações são apenas alguns exemplos.

A Lei de Biossegurança vigente no Brasil é a Lei n. 11.105, de 24 de março de 2005, que revogou a Lei $n^{\circ}$ 8.974, de 05 de janeiro de 1995. Essa lei traz expressamente a necessidade de que se respeite o princípio da precaução, quando se tratar de organismos geneticamente modificados. 
Por ser o segundo país em termos de áreas cultivadas com transgênicos no mundo, fica a dúvida se o Brasil vem respeitando o referido princípio. Nesse sentido, um caso bastante polêmico, o da soja transgênica Roundup Ready, demonstra que as regras que envolvem os organismos geneticamente modificados estão cada vez mais flexíveis e parecem buscar atender os interesses dos seus produtores em detrimento daqueles da população.

Não se pode deixar de aplicar o princípio da precaução quando uma determinada prática acarreta riscos desconhecidos. No caso em tela, tanto a Constituição Federal, quanto a Lei de Biossegurança, reforçam essa necessidade.

Diante de todo o exposto, e diante das incertezas que envolvem os OGM, além do fato de que seus efeitos podem ser irreversíveis, tanto para a saúde humana quanto para o meio ambiente, conclui-se pela incontroversa incidência do princípio da precaução a toda a problemática envolvendo a questão dos OGM e, mais especificamente, dos transgênicos.

\section{REFERÊNCIAS}

BARTH, Wilmar Luiz. Engenharia genética e Bioética. Rev. Trim, Porto Alegre, v. 35, n. 149, p. 361-391, set. 2005. Disponível em: https://core.ac.uk/download/pdf/25532231.pdf. Acesso em: 18 fev. 2021.

BRAMMER, Sandra Patussi. Variabilidade e diversidade genética vegetal: requisito fundamental para um programa de melhoramento. Passo Fundo: Embrapa Trigo, 2002. Disponível em: http://www.cnpt.embrapa.br/biblio/p_do29.pdf. Acesso em: 25 fev. 2021.

BRASIL. Constituição da República Federativa do Brasil de 1988. Atualizada até a Emenda Constitucional $\mathrm{n}^{\circ}$ 107, de 2020. Disponível em:

http://www.planalto.gov.br/ccivil_03/constituicao/constituicao.htm. Acesso em: 26 fev. 2021.

BRASIL. Decreto $n^{\circ} 4.680$, de 24 de abril de 2003. Regulamenta o direito à informação, assegurado pela Lei no 8.078, de 11 de setembro de 1990, quanto aos alimentos e ingredientes alimentares destinados ao consumo humano ou animal que contenham ou sejam produzidos a partir de organismos geneticamente modificados, sem prejuízo do cumprimento das demais normas aplicáveis. Disponível em: http://www.planalto.gov.br/ccivil_03/decreto/2003/d4680.htm. Acesso em: 26 fev. 2021.

BRASIL. Lei n ${ }^{\circ} 11.105$, de 24 de março de 2005. Estabelece normas de segurança e mecanismos de fiscalização de atividades que envolvam organismos geneticamente modificados - OGM e seus derivados e dá outras providências. Disponível em: http://www.planalto.gov.br/ccivil_03/_ato2004-2006/2005/lei/111105.htm. Acesso em: 26 fev. 2021.

CAMARA, Maria Clara Coelho; GUILAM, Maria Cristina Rodrigues; NODARI, Rubens Onofre. Análise do debate sobre alimentos transgênicos no Congresso Nacional. Vigilância 
Sanitária em Debate, Rio de Janeiro: Fiocruz, v. 1, n. 1, p. 25-33, 2013. Disponível em: http://www6.ensp.fiocruz.br/visa/files/12-173-1-PB.pdf. Acesso em: 26 fev. 2021.

CAMPO, Bichos de. Na Copa dos transgênicos, Brasil é vice e Argentina ocupa o terceiro lugar: Os dois países da América do Sul só perdem para os EUA, que lideram a produção de alimentos geneticamente modificados. Brasil de Fato, 04 jul. 2018. Disponível em: https://www.brasildefato.com.br/2018/07/04/na-copa-dos-transgenicos-brasil-e-vice-eargentina-ocupa-o-terceiro-lugar. Acesso em: 26 fev. 2021.

CAPALBO, Deise Maria Fontana. Manual de Biossegurança da Embrapa Meio Ambiente: boas práticas na manipulação de experimentos com organismos geneticamente modificados. Jaguariúna: Embrapa Meio Ambiente, 2016. Disponível em: https://ainfo.cnptia.embrapa.br/digital/bitstream/item/143337/1/D-102.pdf. Acesso em: 25 fev. 2020.

COSTA, Thadeu Estevam Moreira Maramaldo et al. Avaliação de riscos dos organismos geneticamente modificados. Ciência e Saúde Coletiva, Rio de Janeiro, v. 16, n. 1, 2011. Disponível em: https://www.scielo.br/scielo.php?script=sci_arttext\&pid=S141381232011000100035. Acesso em: 26 fev. 2021.

CROP YELDS, World, 1961 to 2018. Ourworldindata, 2018. Disponível em: https://ourworldindata.org/grapher/key-crop-yields. Acesso em: 26 fev. 2021.

DINIZ, Maria Helena. O estado atual do biodireito. 10. ed. São Paulo: Saraiva, 2017.

EUA E BRASIL continuam a liderar a produção de trangênicos no mundo. Sociedade Nacional de Agricultura, 03 dez. 2020. Disponível em: https://www.sna.agr.br/eua-e-brasilcontinuam-a-liderar-a-producao-de-transgenicos-no-mundo/. Acesso em: 26 fev. 2021.

FOOD AND AGRICULTURE ORGANIZATION. Committee on Agriculture.

Biotechnology, 1999. Disponível em: http://www.fao.org/home/en/. Acesso em: 25 fev. 2021.

HERMANN, André. Os transgênicos na modernidade: uma evolução na agricultura. Profissão Biotec, 19 mar. 2020. Disponível em: https://profissaobiotec.com.br/transgenicosmodernidade-evolucao-agricultura/. Accesso em: 26 fev. 2021.

MALISZEWSKI, Eliza. STF deve decidir sobre liberação de transgênicos: Supremo julga ação que pode colocar em xeque as biotecnologias GM no país. Agrolink, 10 fev. 2021. Disponível em: https://www.agrolink.com.br/noticias/stf-deve-decidir-sobre-liberacao-detransgenicos_445924.html. Acesso em: 26 fev. 2021.

NOGUEIRA JUNIOR, Sebastião. Soja Transgênica: o impasse continua. IEA - Instituto Econômico Agrícola, 26 jul. 2005. Disponível em: http://www.iea.sp.gov.br/out/LerTexto.php?codTexto=2870. Acesso em: 26 fev. 2021. 
O VÍRUS que o governo australiano importou da América do Sul para matar coelhos. BBC, 27 maio 2018. Disponível em: https://www.bbc.com/portuguese/internacional-44275162. Acesso em: 10 set. 2021.

OLIVEIRA, Cida de. Nova resolução facilita ainda mais a liberação de transgênicos no Brasil. Rede Brasil Atual, 15 jan. 2020. Disponível em:

https://www.redebrasilatual.com.br/ambiente/2020/01/cntbio-facilita-liberacao-transgenicos/. Acesso em: 26 fev. 2021.

OLIVEIRA FILHO, Enio Walcácer de. Reflexões sobre os Organismos Geneticamente Modificados - OGMs e o princípio da precaução no Biodireito. Vertentes do Direito: UFT Universidade Federal do Tocantins, v. 1, n. 1, 2014 Disponível em:

https://webcache.googleusercontent.com/search?q=cache:f16OMA3hF20J:https://sistemas.uft .edu.br/periodicos/index.php/direito/article/download/814/8021/+\&cd=6\&hl=pt-

BR\&ct=clnk\&gl=br. Acesso em: 27 fev. 2021.

RIBEIRO, Isabelle Geoffroy; MARIN, Victor Augustus. A falta de informação sobre os Organismos Geneticamente Modificados no Brasil. Ciência e saúde coletiva, Rio de Janeiro, v. 17, n. 2, p. 359-368, fev. 2012. Disponível em:

https://www.scielo.br/scielo.php?script=sci_arttext\&pid=S1413-81232012000200010. Acesso em: 23 fev. 2021.

ROSA, Antonio do Nascimento; MENEZES, Gilberto Romeiro de Oliveira; EGITO, Andréa Alves do. Recursos genéticos e estratégias de melhoramento. In: ROSA, Antonio do Nascimento et al. (ed.). Melhoramento genético aplicado em gado de corte: Programa GENEPLUS-EMBRAPA, Brasília: Embrapa, 2013.

SAIBA o que são os alimentos transgênicos e quais os seus riscos. IDEC: Instituto Brasileiro de Defesa ao Consumidor, 22 out. 2019. Disponível em:

https://idec.org.br/zhomologacao/consultas/dicas-e-direitos/saiba-o-que-sao-os-alimentostransgenicos-e-quais-os-seus-

riscos?utm_campaign=DSA_|_Target_+35\&utm_adgroup=DSA_|_Dicas_e_Direitos\&creativ $\mathrm{e}=385938909071 \&$ keyword=\&gclid=CjwKCAiA1 eKBBhBZEiwAX3gq130sDsr096A-

LuahUR54xXeGXBCFGWoLljF9Uh3cC5yvTk0WDkckGhoCPRQQAvD_BwE. Acesso em: 26 fev. 2021.

SOJA transgênica, a grande polêmica do ano. Agrolink, 31 dez. 2003. Disponível em: https://www.agrolink.com.br/noticias/soja-transgenica--a-grande-polemica-doano_14551.html\#: :text=Outra\%20medida\%20pol\%C3\%AAmica\%20da\%20Medida,da\%20 Argentina\%20por\%20produtores\%20ga\%C3\%BAchos. Acesso em: 26 fev. 2021.

ULTCHAK, Alessandra Alvissus de Melo Salles. Organismos Geneticamente Modificados: a legalização no Brasil e o desenvolvimento sustentável. Interthesis, Florianópolis, v. 15, n. 02, p. 125-142, maio/ago.2018. Disponível em:

https://periodicos.ufsc.br/index.php/interthesis/article/view/1807-

1384.2018v15n2p125/36772. Acesso em: 23 fev. 2021. 
VARGAS, Bruna Damasceno et al. Biotecnologia e alimentos geneticamente modificados: uma revisão. Contexto e saúde, Unijuí, v. 18, n. 35, p. 19-26, jul./dez. 2018. Disponível em: https://webcache.googleusercontent.com/search?q=cache:nI5pGXjaHqQJ:https://www.revista s.unijui.edu.br/index.php/contextoesaude/article/view/5591/5953+\&cd=8\&hl=pt$\mathrm{BR} \& \mathrm{ct}=\mathrm{clnk} \& \mathrm{gl}=\mathrm{br}$ 